\title{
ISOLASI DAN KARAKTERISASI BAKTERI YANG DIISOLASI DARI LARVA IKAN KERAPU HIBRIDA CANTIK YANG TERSERANG PENYAKIT EKOR BUNTUNG
}

\author{
Zafran $^{\mathrm{a} *}$, Suko Ismi ${ }^{\mathrm{a}}$, Indah Mastuti ${ }^{\mathrm{a}}$, dan Ketut Mahardika ${ }^{\mathrm{a}}$ \\ ${ }^{a}$ Balai Besar Riset Budidaya Laut dan Penyuluhan Perikanan, Gondol, Bali, Indonesia \\ *Koresponden penulis: zafran16@yahoo.com
}

\begin{abstract}
Abstrak
Budidaya ikan kerapu sudah berkembang pesat di Indonesia. Beberapa tahun belakangan mulai berkembang jenis kerapu hibrida, antara lain kerapu hibrida cantik. Salah satu kendala dalam pembenihan ikan kerapu hibrida cantik adalah terjadinya serangan penyakit yang menyebabkan sirip ekor ikan jadi buntung. Penyakit ini biasanya disebabkan oleh infeksi bakteri. Penelitian ini bertujuan untuk mendapatkan isolat bakteri dari ekor larva ikan kerapu hibrida cantik dan mengetahui karakteristiknya. Dari hasil isolasi didapatkan empat isolat bakteri murni dimana dua isolat tumbuh baik pada media cytophaga agar membentuk koloni berwarna keputih-putihan dan dua isolat lainnya tumbuh baik pada media TCBS agar membentuk koloni berwarna hijau. Isolat bakteri 1 dan 2 sensitif terhadap antibiotik chloramphenicol dan oxytetracyclin tetapi resisten terhadap antibiotik ampicillin, novobiocin, erythromycin, streptomycin, dan penicillin. Di pihak lain, isolat bakteri 3 dan 4 hanya sensitif terhadap antibiotik chloramphenicol. Nilai konsentrasi hambat minimum antibiotik oxytetracyclin terhadap bakteri isolat 1 dan 2 adalah $62,5 \mathrm{mg} / \mathrm{L}$, dan terhadap isolat 3 dan 4 adalah $250 \mathrm{mg} / \mathrm{L}$. Antibiotik erysanbe 500 tidak efektif menghambat pertumbuhan keempat bakteri uji sampai konsentrasi $1000 \mathrm{mg} / \mathrm{L}$. Konsentrasi hambat minimum antibiotik inrofloxs-25 untuk bakteri isolat 1 dan 2 adalah $31,2 \mathrm{mg} / \mathrm{L}$, sedangkan untuk bakteri isolat 3 adalah 62,5 $\mathrm{mg} / \mathrm{L}$ dan untuk bakteri isolat 4 adalah $15,6 \mathrm{mg} / \mathrm{L}$.
\end{abstract}

Kata Kunci : Ekor buntung, infeksi bakteri, kerapu hibrida cantik

\begin{abstract}
Grouper cultures have been developed in Indonesia. Recently, the hybrid groupers also have been produced in hatcheries, including hybrid grouper cantik. One of problems faced in order to produce seeds of hybrid grouper cantik in hatchery is mortality of larvae do to fin rot diseases. This disease usually caused by bacterial infection. The aims of this study were to isolate the bacteria from caudal fin of diseased fish and to determine their characteristics. Four pure isolates of bacteria have been collected. Two isolates of bacteria grown on cytophaga agar with whitish colony color and two other isolates grown on TCBS agar with green colony color. Isolates 1 and isolate 2 were sensitive to chloramphenicol and oxytetracyclin but resistant to ampicillin, novobiocin, erythromycin, streptomycin, and penicillin. On the other hand, isolates 3 and isolate 4 were sensitive only to chloramphenicol. Minimum inhibitory concentration of oxytetracyclin for isolates 1 and 2 were $62.5 \mathrm{mg} / \mathrm{L}$ and for isolates 3 and 4 were $250 \mathrm{mg} / \mathrm{L}$. Antibiotic erysanbe 500 was not effective to inhibit the growth of all four tested isolates up to concentration of $1000 \mathrm{mg} / \mathrm{L}$. Minimum inhibitory concentration of antibiotic inrofloxs- 25 for isolates 1 and 2 were $31.2 \mathrm{mg} / \mathrm{L}, 62.5 \mathrm{mg} / \mathrm{L}$ for isolate 3 and $15.6 \mathrm{mg} / \mathrm{L}$ for isolate 4 , respectively.
\end{abstract}

Keywords : Bacterial infection, fin rot, hybrid grouper cantik,

\section{PENDAHULUAN}

Budidaya ikan kerapu sudah berkembang pesat dan menjadi komoditas perikanan penting di trend untuk hibridisasi beberapa jenis kerapu Indonesia. Beberapa tahun belakangan ini ada di hatchery sehingga dihasilkan apa yang dikenal dengan ikan kerapu cantang dan ikan kerapu cantik. Kerapu cantang adalah hasil persilangan antara betina kerapu macan, Epinephelus fuscoguttatus dengan jantan kerapu kertang Epinephelus lanceolatus. Sedangkan kerapu cantik adalah hasil persilangan betina kerapu macan, E. fuscoguttatus dengan jantan kerapu batik, E. microdon [1]. Kerapu hibrida 
memiliki laju pertumbuhan yang lebih cepat dan tingkat kanibalisme yang lebih rendah dibanding ikan kerapu macan [2]. Karena itu tidak heran kalau permintaan pasar akan benih kerapu hibrida meningkat.

Pada awalnya usaha pembenihan ikan kerapu cantik berjalan dengan lancar. Tetapi belakangan ini mulai terjadi masalah, antara lain terjadinya penyakit busuk sirip ekor atau penyakit ekor buntung (Gambar 1). Walaupun ikan yang sakit ini dapat sembuh tetapi struktur ekor yang sudah terlanjur rusak tidak dapat pulih kembali sehingga ekor ikan tetap berbentuk lancip. Benih ikan dengan kondisi ekor lancip tersebut tidak akan laku dijual. Karena itu tidak heran kalau para pembenih ikan kerapu di hatchery memilih membuang ikan sakit tersebut dibandingkan untuk mempertahankan atau mengobatinya.

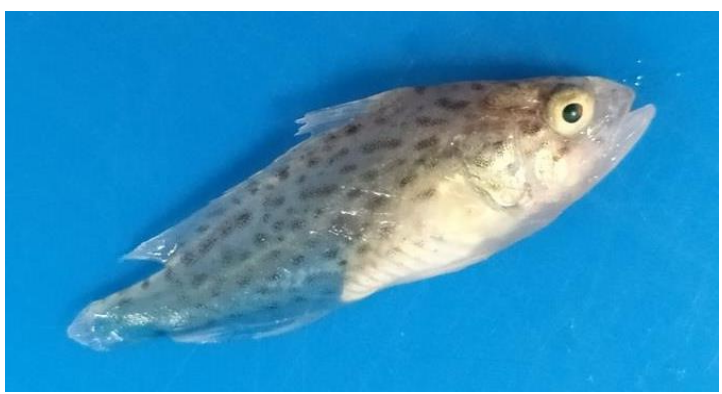

Gambar 1. Busuk ekor pada kerapu cantik

Sampai sekarang belum ada informasi yang valid tentang penyebab penyakit ekor buntung pada larva/benih ikan kerapu cantik. Hasil pengamatan mikroskopis terhadap ekor buntung tidak ditemukan adanya infeksi parasit. Namun demikian dari beberapa referensi dikatakan bahwa penyebab ekor buntung atau busuk sirip pada ikan adalah infeksi bakteri $[3,4,5,6]$. Penyakit busuk sirip biasanya diawali dengan erosi atau kerusakan pada ujung sirip yang kemudian berkembang jadi nekrosis.

Tujuan dari penelitian ini adalah untuk mengetahui karakteristik dari bakteri yang diisolasi dari ekor larva ikan kerapu hibrida cantik yang terinfeksi penyakit ekor buntung. Hasil penelitian ini diharapkan dapat berkontribusi dalam pengembangan metode pengendalian penyakit ekor buntung pada larva/benih ikan kerapu, khususnya kerapu hibrida cantik.

\section{METODE PENELITIAN}

\section{Waktu dan Tempat Penelitian}

Penelitian dilakukan pada Bulan Agustus sampai September 2019. Benih ikan kerapu hibrida cantik dengan gejala klinis ekor buntung diperoleh dari hatchery di Besuki, Jawa Timur. Ikan sakit dibawa dalam keadaan hidup ke Laboratorium Patologi Balai Besar Riset Budidaya Laut dan penyuluhan Perikanan, Gondol, Bali, menggunakan kantong plastik yang diisi air laut dan oksigen.

\section{Isolasi Bakteri}

Bakteri diisolasi dari ekor larva ikan kerapu hibrida cantik berukuran sekitar $3 \mathrm{~cm}$. Ekor ikan yang mangalami penyakit dipotong dan dicuci dengan ar laut steril. Ekor ikan tersebut selanjutnya dimasukkan ke dalam tabung reaksi yang berisi air laut steril dan diaduk menggunakan fortex. Masing-masing $0,1 \mathrm{ml}$ air laut tersebut selanjutnya diinokulasikan ke atas media Cytophaga agar dan TCBS agar. Media tersebut selanjutnya diinkubasi pada suhu $30^{\circ} \mathrm{C}$. Setelah 48 jam maka bakteri yang tumbuh dominan diambil dan dimurnikan pada media $\mathrm{TSA}+2 \% \mathrm{NaCl}$.

\section{Uji sensitivitas bakteri terhadap obat}

Uji sensitivitas bakteri terhadap obat/antibiotik dilakukan menggunakan kertas cakram (paper disc) yang sudah mengandung antibiotik. Tujuh jenis antibiotik telah diujikan pada penelitian ini, yaitu oxytetracyclin (200 $\mu \mathrm{g})$, ampicilin $(30 \mu \mathrm{g})$, novobiocin $(20 \mu \mathrm{g})$, erythromycin $(15 \mu \mathrm{g})$, penicillin (10 IU), streptomycin $(10 \mu \mathrm{g})$, dan chloramphenicol $(30 \mu \mathrm{g})$. Sebagai kontrol negatif digunakan kertas cakram yang tidak mengandung antibiotik. Masing-masing kertas cakram di atas ditempatkan pada media agar (TSA $+2 \%$ $\mathrm{NaCl})$ yang telah diinokulasikan bakteri uji. Media agar tersebut selanjutnya diinkubasikan pada suhu $30^{\circ} \mathrm{C}$ selama 24 jam. Tingkat sensitivitas bakteri terhadap antibiotik ditentukan berdasarkan besarnya zona hambat dari masing-masing antibiotik tersebut berpedoman pada [7]. Pelaksanaan uji sensitivitas antibiotik terhadap bakteri dapat dilihat pada Gambar 2. 


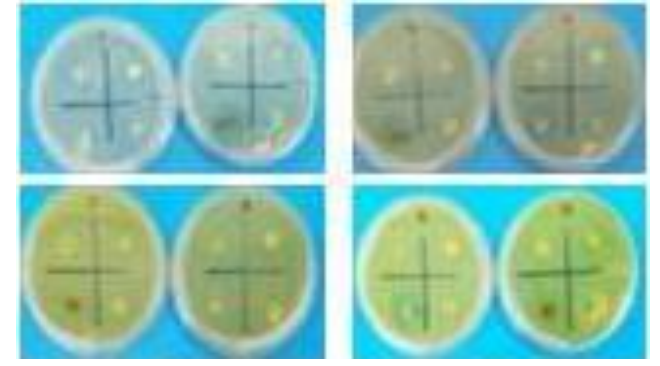

Gambar 2. Uji sensitivitas bakteri terhadap antibiotik menggunakan kertas cakram

\section{Penentuan konsentrasi hambat minimum}

Konsentrasi hambat minimal (Minimum Inhibitory Concentration/MIC) dilakukan dengan cara melarutkan antibiotik uji dalam media TSB (Tryptic Soy Broth $+2 \%$ $\mathrm{NaCl}$ ).Tiga jenis antibiotik digunakan dalam penelitian ini, yaitu oxytetracyclin, Erysanbe 500 (erythromycin), dan inrofloxs-25 (Enrofloxacin). Melalui teknik pengenceran dua kali maka didapatkan konsentrasi akhir $1000 \mathrm{mg} / \mathrm{L}, 500 \mathrm{mg} / \mathrm{L}, 250 \mathrm{mg} / \mathrm{L}, 125 \mathrm{mg} / \mathrm{L}$, $62,5 \mathrm{mg} / \mathrm{L}, 31,2 \mathrm{mg} / \mathrm{L}, 15,6 \mathrm{mg} / \mathrm{L}, 7,8 \mathrm{mg} / \mathrm{L}$, dan 3,9 mg/L. Sebagai kontrol adalah TSB tanpa antibiotik. Ke dalam masing-masing konsentrasi antibiotik tersebut selanjutnya diinokulasikan bakteri uji dan diinkubasikan pada suhu $30^{\circ} \mathrm{C}$ selama 24 jam. Pada TSB kontrol tidak dilakukan inokulasi bakteri. Nilai MIC ditentukan dengan cara melihat tidak adanya perubahan kekeruhan media uji sebagaimana pada kontrol (Gambar 3).

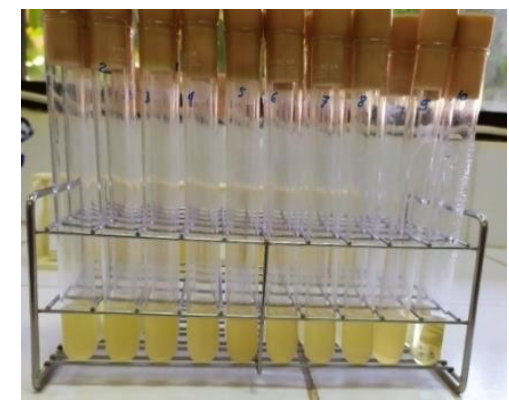

Gambar 3. Penentuan konsentrasi hambat minimal dengan metode media cair

\section{HASIL DAN PEMBAHASAN}

\section{Isolasi Bakteri}

Dari ekor larva ikan kerapu hibrida sakit telah diisolasi empat isolat bakteri, dua isolat dari media cytophaga agar dan dua isolat lagi dari media TCBS agar. Karakteristik keempat isolat tersebut disajikan dalam Tabel 1.

Tabel 1. Karakteristik bakteri yang diisolasi dari ekor larva ikan kerapu hibrida cantik sakit

\begin{tabular}{|c|c|c|c|c|}
\hline \multirow[t]{2}{*}{ Karakter } & \multicolumn{4}{|c|}{ Tsolat } \\
\hline & 1 & 2 & $\overline{3}$ & 4 \\
\hline $\begin{array}{l}\text { Media } \\
\text { isolasi }\end{array}$ & Cytophaga & Cytophaga & TCBSA & TCBSA \\
\hline $\begin{array}{l}\text { Warna } \\
\text { koloni }\end{array}$ & $\begin{array}{l}\text { Keputih- } \\
\text { putihan }\end{array}$ & $\begin{array}{c}\text { Keputih- } \\
\text { putihan }\end{array}$ & Hijau & Hijau \\
\hline $\begin{array}{c}\text { Tumbuh } \\
\text { pada } \\
\text { TCBSA }\end{array}$ & Hijau & Hijau & Hijau & Hijau \\
\hline $\begin{array}{c}\text { Pewarnaan } \\
\text { Gram }\end{array}$ & - & - & - & - \\
\hline Oksidase & + & + & + & + \\
\hline $\begin{array}{l}\text { Vibrio static } \\
\text { agent (0/129) }\end{array}$ & Sensitif & Sensitif & Sensitif & Sensitif \\
\hline
\end{tabular}

Dari hasil uji tumbuh pada pada media TCBS agar (media selektif untuk bakteri Vibrio), ternyata kedua isolat yang diisolasi menggunakan media cytophaga agar juga tumbuh pada media TCBS agar dengan membentuk koloni berwarna hijau. Keempat isolat adalah Gram-negatif, oksidase positif, dan sensitif terhadap "vibrio static agent" (0/129). Berdasarkan karakteristik tersebut maka besar kemungkinan bahwa keempat isolat bakteri ini tergolong ke dalam kelompok bakteri Vibrio [8]. Sebelumnya telah dilaporkan bahwa penyebab penyakit borok dan busuk sirip ekor pada larva/benih ikan kakap putih (Lates calcarifer) di hatchery adalah Vibrio vulnificus [9]. Namun demikian perlu dilakukan identifikasi secara molekuler guna mengetahui jenis bakteri tersebut secara pasti.

\section{Uji sensitivitas bakteri terhadap antibiotik}

Hasil uji sensitivitas bakteri terhadap tiga macam antibiotik disajikan dalam Tabel 2 . Pada Tabel 2 terlihat bahwa keempat isolat bakteri uji sensitif terhadap antibiotik chloramphenicol yang ditunjukkan oleh zona bening yang berkisar dari 19,54 $\mathrm{mm}-22,31$ $\mathrm{mm}$. Dengan data zona hambat tersebut maka dapat diklasifikasikan bahwa antibiotik chloramphenicol mempunyai daya hambat 
yang kuat terhadap keempat isolat bakteri uji. Hasil berbeda ditunjukkan bakteri uji terhadap antibiotik oxytetracyclin. Isolat 1 dan isolat 2 sensitif terhadap oxytetracyclin dengan diameter zona bening lebih dari $20 \mathrm{~mm}$. Sebaliknya isolat 3 dan isolat 4 berdasarkan (Greenwood, 1995 dalam Fitri, 2010) diklasifikasikan tidak sensitif terhadap oxytetracyclin. Keempat isolat tidak sensitif terhadap lima antibiotik uji lainnya, yaitu ampicillin, novobiocin, erythromycin, streptomycin, dan penicillin.

Tabel 2. Uji sensitivitas bakteri terhadap antibiotik

\begin{tabular}{ccccc}
\hline Antibiotik & \multicolumn{4}{c}{ Zona hambat (mm) pada isolat } \\
\cline { 2 - 5 } Chloramphenicol & 22.31 & 19.54 & 20.27 & 20.14 \\
Oxytetracyclin & 22.51 & 20.13 & 0 & 9.31 \\
Ampicilin & 0 & 0 & 0 & 0 \\
Novobiocin & 0 & 0 & 0 & 0 \\
Erythromycin & 0 & 0 & 0 & 0 \\
Streptomycin & 0 & 7.52 & 0 & 0 \\
Penicillin & $\mathbf{0}$ & $\mathbf{0}$ & $\mathbf{0}$ & $\mathbf{0}$ \\
Kontrol & $\mathbf{0}$ & $\mathbf{0}$ & $\mathbf{0}$ & $\mathbf{0}$ \\
\hline
\end{tabular}

\section{Konsentrasi hambat minimum antibiotik terhadap bakteri}

Hasil penentuan konsentrasi hambat minimum oxytetracyclin (OTC) terhadap bakteri uji menunjukkan hasil yang berbeda. Bakteri isolat 1 dan isolat 2 tidak tumbuh pada oxytetracyclin mulai konsentrasi $62,25 \mathrm{mg} / \mathrm{L}$, sedangkan bakteri isolat 3 dan isolat 4 baru terhambat pertumbuhannya pada oxytetracyclin mulai konsentrasi $250 \mathrm{mg} / \mathrm{L}$. Data tersebut menunjukkan bahwa nilai konsentrasi hambat minimum oxytetracyclin untuk isolat 3 dan isolat 4 adalah empat kali lebih tinggi dibanding nilai konsentrasi hambat minimal oxytetracyclin terhadap isolat 1 dan isolat 2. Hasil lengkap uji penentuan konsentrasi hambat minimum oxytetracylin terhadap bakteri uji disajikan dalam Tabel 3 .
Tabel 3. Konsentrasi hambat minimum antibiotik oxytetracyclin terhadap isolat bakteri uji

\begin{tabular}{|c|c|c|c|c|}
\hline \multirow{3}{*}{$\begin{array}{c}\text { Konsentrasi } \\
\text { oxytetracyclin } \\
(\mathrm{mg} / \mathrm{L})^{\prime}\end{array}$} & \multicolumn{4}{|c|}{ Tsolat } \\
\hline & 1 & 2 & 3 & 4 \\
\hline & & & & \\
\hline 1000 & - & - & - & - \\
\hline 500 & - & - & - & - \\
\hline 250 & - & - & - & - \\
\hline 125 & - & - & + & + \\
\hline 62.5 & - & - & + & + \\
\hline 31.2 & + & + & + & + \\
\hline 15.6 & + & + & + & + \\
\hline 7.8 & + & + & + & + \\
\hline 3.9 & + & + & + & + \\
\hline 0 (Kontrol) & - & - & - & - \\
\hline
\end{tabular}

Keterangan:(+) : Keruh (Bakteri tumbuh)

$(-)$ : Jernih (Bakteri tidak tumbuh)

Selain banyak digunakan dalam pengendalian penyakit bakterial di budidaya perikanan laut, pada perikanan air tawar penggunaan OTC juga sangat umum. OTC dengan dosis $45 \mathrm{ppm}$ terbukti efektif mengobati ikan lele (Clarias sp) yang terinfeksi bakteri Edwardsiella tarda [10].

Antibiotik OTC adalah obat yang sering jadi pilihan para pembudidaya ikan untuk mengobati ikan yang terserang penyakit bakterial. Tapi perlu diingat bahwa pemakaian OTC secara rutin dapat berakibat terbentuknya strain-strain bakteri yang resisten terhadap OTC. Apabila limbah hatchery yang mengandung antibiotik, bakteri patogen yang resisten dibuang begitu saja ke perairan umum maka akan menimbulkan dampak negatif kepada lingkungan dan masyarakat sekitarnya. Sebagaimana kita ketahui bahwa beberapa jenis antibiotik yang digunakan di hatchery juga digunakan dalam usaha penyembuhan penyakit pada manusia, misalnya OTC dan chloramphenicol.

Hasil uji konsentrasi hambat minimum antibiotik erysanbe 500 terhadap keempat isolat bakteri menunjukkan bahwa sampai konsentrasi $1000 \mathrm{mg} / \mathrm{L}$ bakteri uji masih tetap bisa tumbuh yang dicirikan dengan perubahan warna media uji menjadi keruh (Tabel 4). 
Tabel 4. Konsentrasi hambat minimum antibiotik erysanbe 500 terhadap isolat bakteri uj

\begin{tabular}{|c|c|c|c|c|}
\hline \multirow{2}{*}{$\begin{array}{l}\text { Konsentrasi } \\
\text { erysanbe } 500\end{array}$} & \multicolumn{4}{|c|}{ Tsolat } \\
\hline & 1 & 2 & 3 & 4 \\
\hline \multicolumn{5}{|l|}{$\left.{ }^{(\mathrm{mg} / \mathrm{L}}\right)^{\prime}$} \\
\hline 1000 & + & + & + & + \\
\hline 500 & + & + & + & + \\
\hline 250 & + & + & + & + \\
\hline 125 & + & + & + & + \\
\hline 62.5 & + & + & + & + \\
\hline 31.2 & + & + & + & + \\
\hline 15.6 & + & + & + & + \\
\hline 7.8 & + & + & + & + \\
\hline 3.9 & + & + & + & + \\
\hline 0 (Kontrol) & - & - & - & - \\
\hline
\end{tabular}

Keterangan:(+) : Keruh (Bakteri tumbuh)

(-) : Jernih (Bakteri tidak tumbuh)

Hasil konfirmasi dengan cara menginokulasikan bakteri dari perlakuan erysanbe 500 dengan konsentrasi tertinggi (1000 mg/L) 24 jam pasca perlakuan menunjukkan bahwa keempat bakteri uji masih tumbuh baik pada media TCBSA. Ada kemungkinan bahwa bakteri uji sudah resisten terhadap antibiotik ini karena sudah digunakan dalam waktu lama di hatchery dimana ikan sampel diperoleh.

Bakteri-bakteri patogen yang dibuang atau lepas ke laut akan berpotensi menjadi masalah bagi hatchery-hatchery ikan lain yang berada pada kawasan tersebut. Bakteri-bakteri tersebut berpotensi menimbulkan kematian apabila menginfeksi ikan-ikan budidaya di hatchery yang terletak dalam satu kawasan dengan hatchery sumber bakteri patogen tersebut. Karena itu perlu kesadaran semua pihak untuk tidak menggunakan antibiotik secara tidak tepat.

Hasil uji menunjukkan adanya variasi nilai konsentrasi hambat minimum antibiotik inrofloxs-25 oleh masing-masing isolat bakteri (Tabel 5). Antibiotik inrofloxs-25 efektif menghambat pertumbuhan bakteri isolat 1 dan isolat 2 pada konsentrasi 31,2 $\mathrm{mg} / \mathrm{L}$. Untuk bakteri isolat 3 nilai konsentrasi hambat terendah antibiotik inrofloxs-25 adalah $62,5 \mathrm{mg} / \mathrm{L}$ dan untuk isolat 4 adalah $15,6 \mathrm{mg} / \mathrm{L}$.
Tabel 5. Konsentrasi hambat minimum antibiotik inrofloxs-25 terhadap isolat bakteri uji

\begin{tabular}{ccccc}
\hline \begin{tabular}{c} 
Konsentrasi \\
inrofloxs-25 \\
$(\mathrm{mg} / \mathrm{L})$ \\
\cline { 2 - 5 } 1000
\end{tabular} & 1 & 2 & 3 & 4 \\
500 & - & - & - & - \\
250 & - & - & - & - \\
125 & - & - & - & - \\
62.5 & - & - & - & - \\
31.2 & - & - & - & - \\
15.6 & - & - & + & - \\
7.8 & + & + & + & - \\
3.9 & + & + & + & + \\
0 (Kontrol) & + & + & + & + \\
\hline Keterangan:(+) & - Keruh (Bakteri tumbuh) & - \\
\hline
\end{tabular}

(-) : Jernih (Bakteri tidak tumbuh)

Antibiotik adalah pilihan yang sangat umum diambil oleh para pembudidaya perikanan baik untuk pencegahan maupun pengobatan apabila ikan peliharaan mereka terserang infeksi bakteri. Pemilihan obat/antibiotik tersebut biasanya didasarkan pada ketersediaan di pasar, tidak didasarkan pada uji laboratorium sehingga hasilnya mengecewakan dimana kematian ikan budidaya tetap terjadi. Pemilihan obat/antibiotik yang tidak tepat, baik jenis maupun dosis/konsentrasinya, berakibat penyakit tidak bisa ditanggulangi. Dampak negatif lainnya adalah terbentuknya strain bakteri yang resisten terhadap antibiotik tersebut dan terjadinya residu antibiotik pada tubuh ikan budidaya dan di lingkungan budidaya ikan itu sendiri.

Resistensi bisa terjadi karena beberapa hal, antara lain penggunaan dosis antibiotik yang tidak tepat, menggunakan antibiotik dalam jangka waktu yang lama, dan penggunaan antibiotik yang terlalu sering. Resistensi timbul karena bakteri mampu mengadakan perubahan secara internal untuk menahan serangan antibiotik yang terjadi secara terus-menerus. Bakteri mempunya kemampuan untuk menghasilkan enzim yang dapat menguraikan antibiotik serta memperkuat membran selnya sehingga tidak dapat ditembus oleh antibiotik. Proses tersebut menyebabkan antibiotik tidak efektif lagi membunuh bakteri penyebab penyakit. Karena itu perlu kehati-hatian dalam memilih 
obat/antibiotik untuk digunakan dalam pengendalian penyakit bakterial pada budidaya ikan.

Selain dengan perbaikan lingkungan media budidaya, metode lain yang lebih aman dalam pengendalian penyakit adalah pemberian vaksin terhadap ikan budidaya. Metode vaksinasi dari penelitian terdahulu sudah terbukti efektif meningkatkan kekebalan terhadap vibriosis pada ikan kerapu bebek [11], kerapu macan [12,13] [14], hibrida cantik [15], dan kerapu sunu [16].

\section{KESIMPULAN}

Dari hasil penelitian ini dapat disimpulkan hal-hal sebagai berikut:

1) Keempat isolat bakteri yang diisolasi dari ekor larva ikan kerapu cantik tumbuh baik pada media TCBSA, Gram-negatif, oksidase positif, dan sensitif terhadap "vibrio static agent" (0/129).

2) Bakteri isolat 1 dan 2 sensitif terhadap chloramphenicol dan oxytetracyclin tetapi tidak sensitif terhadap ampicillin, novobiocin, erythromycin, streptomycin, dan penicillin. Sebaliknya bakteri isolat 3 dan 4 hanya sensitif terhadap chloramphenicol.

3) Konsentrasi hambat minimum antibiotik oxytetracyclin terhadap bakteri isolat 1 dan 2 adalah $62,5 \mathrm{mg} / \mathrm{L}$, dan terhadap isolat 3 dan 4 adalah $250 \mathrm{mg} / \mathrm{L}$.

4) Antibiotik erysanbe 500 tidak efektif menghambat pertumbuhan keempat bakteri uji sampai konsentrasi $1000 \mathrm{mg} / \mathrm{L}$.

5) Konsentrasi hambat minimum antibiotik inrofloxs-25 untuk bakteri isolat 1 dan 2 adalah $31,2 \mathrm{mg} / \mathrm{L}$, sedangkan untuk bakteri isolat 3 adalah $62,5 \mathrm{mg} / \mathrm{L}$ dan untuk bakteri isolat 4 adalah $15,6 \mathrm{mg} / \mathrm{L}$.

\section{UCAPAN TERIMA KASIH}

Penulis mengucapkan terima kasih kepada Saudara Slamet Haryanto, teknisi Laboratorium Patologi, Balai Besar Riset Budidaya Laut dan Penyuluhan Perikanan, Gondol atas bantuannya sehingga penelitian ini bisa terlaksana dengan baik.

\section{DAFTAR PUSTAKA}

[1] S. Ismi, Y.N. Asih, dan D. Kusumawati, "Peningkatan Produksi dan Kualitas Benih Ikan Kerapu Melalui Program Hibridisasi". Jurnal Ilmu Teknologi Kelautan Tropis. Vol. 5, no. 2 , hal. 333342, 2013.

[2] S. Ismi, dan Y.N. Asih, " Pengamatan Perkembangan Benih Kerapu Hybrid Persilangan antara Kerapu Macan (Epinephelus fuscoguttatus) dan Kerapu kertang (Epinephelus lanceolatus"), dalam Prosiding Seminar Nasional Kelautan VI, Universitas Hang Tuah, Surabaya, 18 Juli 2011, hal. 100-104, 2011.

[3] Zafran, D. Roza, I. Koesharyani, F. Johnny, dan K. Yuasa, "Manual for Fish Diseases Diagnosis: Marine fish and crustacean diseases in Indonesia", Gondol Research Station for Coastal Fisheries and Japan International Cooperation Agency. 44 p, 1998.

[4] I. Koesharyani, D. Roza, K. Mahardika, F. Johnny, Zafran, and K.Yuasa, "Manual for Fish Diseases Diagnosis-II, Marine fish and crustacean diseases in Indonesia", K. Sugama, H. Ikenoue, \& S. Kawahara, (eds), Gondol Marine Research for Mariculture, Central Research Institute for Sea Exploration and Fisheries, Department of Marine Affair and Fisheries, and Japan International Cooperation Agency, $49 \mathrm{p}$, 2001.

[5] E.A.Tendencia, E.A. and C.R. LavillaPitogo, "Bacterial diseases", In Diseases of Cultured Groupers. Kazuya Nakazawa and E.R. Cruz-Lacierda (Eds), hal. 1928. 2004.

[6] E. Afrianto, E. Liviawaty, Zafran, dan Hendi 2015, "Penyakit ikan". Penebar Swadaya, Jakarta, 220 hal., 2015.

[7] L. Fitri, "The effect of Michelia alba Bark to the growth of Salmonella typhii and Candida albicans", Jurnal Natural, vol.10 no.1, hal. 27-30, 2010. 
[8] L. Ruangpan and E.A. Tendencia, "Laboratory manual of standardized methods for antimicrobial sensitivity tests for bacteria isolated from aquatic animals and environment", Southeast Asian Fisheries Development Center, Aquaculture Department, Iloilo, Philippines. 55p, 2004.

[9] Zaenuddin, Y.L. Nuraini, A. Faries, dan S. Wahyuningsih, "Pengendalian penyakit vibriosis pada ikan kakap putih", Jurnal Perekayasaan Budidaya Air payau dan Laut, no. 14, hal. 77-83, 2019.

[10] Q. A'yunin, H. Kartikaningsih, S. Andayani, M. Surantika, Fariedah, Fani, A. Soeprijanto, dan N. Bai A, "Efikasi oxytetracycline terhadap kesehatan ikan lele (Clarias sp) yang diinfeksi bakteri Edwardsiella tarda", Joernal of Fisheries and Marine Research, vol. 3, no. 1, hal. 105-110, 2019.

[11] Zafran, D. Roza, dan F. Johnny, "Respons juvenil ikan kerapu bebek (Cromileptes altivelis) terhadap vaksin Vibrio polivalen yang diberikan melalui perendaman", dalam Prosiding Seminar Nasional Biologi, Unsyiah, Banda Aceh, 26-27 November 2011, hal. 222-224, 2011.

[12] Zafran, D. Roza, and F. Johnny. "Immunogenicity and protective effects of formalin-killed polyvalent Vibrio vaccine in tiger grouper (Epinephelus fuscoguttatus)", dalam Proceeding of International Conference of Indonesian Aquaculture, Surabaya, 25-27 October 2010, hal.1098 - 1101, 2010.

[13] Zafran, "Vaksinasi benih ikan kerapu macan (Epinephelus fuscoguttatus) dengan tiga bakteri patogen yang sudah diinaktivasi", Jurnal Ilmu dan Teknologi Kelautan Tropis, vol. 7, no. 2, hal. 629638, 2015.

[14] Zafran, "Efektivitas kombinasi vaksin bakteri polivalen dengan vaksin anti grouper sleepy disease iridovirus pada ikan kerapu macan (Epinephelus fuscoguttatus)", Jurnal Berita Biologi, vol. 15, no 1, hal. 95-100, 2016.

[15] Zafran, D. Roza, K. Mahardika, dan I. Mastuti, "Penentuan perbandingan terbaik tiga antigen vaksin bakteri polivalen dalam meningkatkan imunitas benih ikan kerapu hibrid cantik", dalam Prosiding Seminar Nasional Kelautan XII, Universitas Hang Tuah, Surabaya, hal. D2-65-70, 2017, ISBN: 978-60271063-3-8.

[16] Zafran, D. Roza, K. Mahardika, dan I. Mastuti, "Peningkatan imunitas benih kerapu sunu (Plectropomus leopardus) di hatchery melalui aplikasi vaksin bakteri polivalen", Prosiding Seminar Nasional Kelautan XIII, Universitas Hang Tuah, Surabaya, hal. C1-90-97. 2018, ISBN: 978-602-71063-4-5. 